\title{
Exosome-mediated transfer of CD44 from high-metastatic ovarian cancer cells promotes migration and invasion of low- metastatic ovarian cancer cells
}

\author{
Xiameng Shen ${ }^{1 \dagger}$, Conghui Wang ${ }^{2 \dagger}$, Huihui Zhu' ${ }^{1}$, Yaping Wang ${ }^{1}$, Xinyu Wang ${ }^{1,2,3}$, Xiaodong Cheng ${ }^{1,2,3}$,
} Wanzhong $\mathrm{Ge}^{2,3}$ and Weiguo $\mathrm{Lu}^{1,2,3^{*}}$ [D

\begin{abstract}
Objective: To investigate the detailed roles and mechanisms of tumor-derived exosomes in progression and metastasis of ovarian cancer in vitro.

Methods: Exosomes were isolated by differential centrifugation method; the morphology, size and biological markers of exosomes were separately defined by transmission electron microscopy, nanoS90 and Western blotting; Trans-well chambers assay was used to assess the ability of migration and invasion of recipient cells uptaking the exosomes from HO8910PM cells. The downstream molecule was screened by mass spectrometry.CD44 was identified by western blotting and the function of CD44 was identified by trans-well chambers assay and CCK8 assay.

Results: Exosomes derived from HO8910PM cells could be transferred to HO8910 cells and promote cell migration and invasion in the recipient cells of ovarian cancer. And CD44 could be transferred to the HO8910 cells through exosomes from HO8910PM cells and influence the migration and invasion ability of HO8910 cells.
\end{abstract}

Conclusion: The more aggressive subpopulation can transfer a metastatic phenotype to the less one via secreting exosomes within a heterogeneous tumor. CD44 may be a potential therapeutic approach for ovarian cancer.

Keywords: Exosome, Ovarian cancer, Heterogeneity, Metastasis

\section{Introduction}

Ovarian cancer is the most lethal type in gynecological neoplasms. In the USA, around 22,440 women were diagnosed as ovarian cancer and 14,070 women died from the disease in 2018. The overall 5-year survival rate of ovarian cancer patients was $47 \%$ according to cancer

\footnotetext{
* Correspondence: Ibwg@zju.edu.cn

${ }^{+}$Xiameng Shen and Conghui Wang contributed equally to this work. 'Department of Gynecologic Oncology, Women's Hospital School of Medicine Zhejiang University, No. 1 Xueshi Road, Hangzhou 310006, China 'Women's Reproductive Health Research Laboratory of Zhejiang Province, Women's Hospital School of Medicine Zhejiang University, Hangzhou, China Full list of author information is available at the end of the article
}

statistics, but dropped to $29 \%$ in advanced stage patients, gathered over the period from 2006 to 2012 [42]. The high mortality related to ovarian cancer is due to its aggressive behavior and metastatic potential, but the underlying mechanism remains unclear.

Cancers, including ovarian cancer, frequently display substantial intra-tumor heterogeneity in virtually all distinguishable phenotypic features, such as cellular morphology, gene expression (including the expression of cell surface markers and growth factors and hormonal receptors), metabolism, motility, angiogenic, proliferative, immunogenic, and metastatic potential $[9,11,17,28]$.

(c) The Author(s). 2021 Open Access This article is licensed under a Creative Commons Attribution 4.0 International License, which permits use, sharing, adaptation, distribution and reproduction in any medium or format, as long as you give appropriate credit to the original author(s) and the source, provide a link to the Creative Commons licence, and indicate if changes were made. The images or other third party material in this article are included in the article's Creative Commons licence, unless indicated otherwise in a credit line to the material. If material is not included in the article's Creative Commons licence and your intended use is not permitted by statutory regulation or exceeds the permitted use, you will need to obtain permission directly from the copyright holder. To view a copy of this licence, visit http://creativecommons.org/licenses/by/4.0/ The Creative Commons Public Domain Dedication waiver (http://creativecommons.org/publicdomain/zero/1.0/) applies to the data made available in this article, unless otherwise stated in a credit line to the data. 
However, all those heterogeneous cells tend to homogenous in the similiar microenvironment. For example, all cancer cells eventually present similar aggressive potential via intercellular interactions without outside intervention. And perhaps there might be a network of biological interactions among the distinct clones. Understanding the mechanism would help to improve the treatment strategies for cancer.

Exosomes are small extracellular vesicles (EVs), ranging from 30 to $150 \mathrm{~nm}$ in size. They are produced by all cells and present in all body fluids $[6,20]$. In the past, releasing exosomes was considered as a form of disposing of cellular wastes [30]. Today, exosomes are emerging as excellently equipped vehicles for information transfer between cells [5, 47]. The protein and microRNA content of exosomes has been implicated in various intracellular processes that mediate oncogenesis, tumor spread, and drug resistance. Tumor cells actively produce, release, and utilize exosomes to promote tumor growth and convey molecular and genetic messages from tumor cells to normal or other abnormal cells residing at close or distant sites. However, it remains unknown whether exosomes are involved in the process of homogenization of heterogeneous tumor cells, and the content of exosomes which may work still needs further research.

In this study, we presented the evidence that exosomes derived from high metastatic ovarian cells can be transferred to low metastatic ovarian cancer cells and promote the migration and invasion of recipient cells. Furthermore, we intended to find the molecules in exosomes through MS analysis and identified CD44 in transferred exosomes was a mediator in promoting metastatic behavior during this process. Our findings may provide a novel approach for ovarian cancer therapeutics.

\section{Materials and methods \\ Cell culture}

The human epithelial ovarian cancer cell lines, HO8910 and HO8910PM, were acquired from the Women's Hospital, School of Medicine, Zhejiang University, where they were tested and authenticated. They were not cultured continuously for more than 3 months. Adherent HO8910 and HO8910PM cells were cultured in Roswell Park Memorial Institute (RPMI)-1640 medium (BI, Kibbutz Beit-Haemek, Israel), supplemented with $10 \%$ fetal bovine serum (FBS) (Invitrogen, New York, USA) and $100 \mathrm{U} / \mathrm{mL}$ penicillin, and $100 \mu \mathrm{g} / \mathrm{mL}$ streptomycin, maintained at $37^{\circ} \mathrm{C}$ in $5 \% \mathrm{CO}_{2}$ and detached using tryp$\sin /$ EDTA solution.

\section{Plasmids transfection}

$\mathrm{CD} 44$ variant1 was cloned into the $\mathrm{pEX}-2$ vector, $\mathrm{X}$ treme GENE HP DNA Transfection Reagent (Roche,
Basel, Switzerland) was used for transient transfection (Roche, Basel, Switzerland) following the manufacturer's protocols. For G418 (Sigma-Aldrich, St. Louis, USA) selection, cells were transfected with plasmid for $24 \mathrm{~h}$ and treated with $500 \mu \mathrm{g} / \mathrm{mL} \mathrm{G418}$ for 14 days.

\section{Migration assay}

Trans-well plates (24-well, 8-mm pore size; Costar, Cambridge, MA, USA) were used to conduct the migration assay. The lower chamber of the trans-well plate was filled with $500 \mathrm{uL}$ of 1640 medium containing $10 \%$ FBS. Cells $\left(2 \times 10^{5}\right)$ suspended in 1640 medium without FBS were added to the upper chamber. The plate was incubated at $37^{\circ} \mathrm{C}$ with $5 \% \mathrm{CO}_{2}$ in air for $24 \mathrm{~h}$. At the end of the assay, after removing non-migrating cells by scraping from the top of the filter, each filter was fixed in methanol, stained with $0.5 \%$ crystal violet (Sigma-Aldrich, St. Louis, USA) and cells were observed by a light microscope at $400 \times$ magnification. Each assay was performed in triplicate; migrating cells were counted in at least five high power fields per well.

\section{Matrigel invasion assay}

In vitro invasion assay was evaluated in trans-well chambers. Briefly, cells $\left(3 \times 10^{5}\right)$ suspended in serum-free RPMI 1640 medium with $8 \mu \mathrm{m}$ pore filter coated with 1: 12 matrigel (BD Biosciences, San Jose, CA, USA) and exposed to medium supplemented with $10 \%$ of FBS for 24 $h$ at $37^{\circ} \mathrm{C}$ in $5 \% \mathrm{CO}_{2}$. At the end of the assay, after removing non-invading cells by scraping from the top of the filter, each filter was fixed in methanol, stained with $0.5 \%$ crystal violet, and cells were observed by a light microscope at $400 \times$ magnification. Each assay was performed in triplicate, invading cells were counted in at least five high power fields per well.

\section{Cell viability assays}

Cells were seeded (4000 cells per well) in 96-well plates, after adhering to the plates for $24 \mathrm{~h}, 48 \mathrm{~h}, 72 \mathrm{~h}$, and $96 \mathrm{~h}$, the cell viability was determined with Cell Counting Kit8 (Dojindo, Japan), following the manufacturer's protocols.

\section{Isolation of exosomes}

When reached $50-60 \%$ confluency, cells were washed with PBS twice and incubated with RPMI-1640 containing $10 \%$ exosome-depleted FBS (prepared by $16 \mathrm{~h}$ overnight ultracentrifugation at $120,000 \times \mathrm{g}$ at $4{ }^{\circ} \mathrm{C}$ ) for $48 \mathrm{~h}$. Exosomes were isolated from the conditioned medium by ultracentrifugation. In brief, conditioned medium was centrifuged at $300 \times \mathrm{g}$ for $10 \mathrm{~min}$, then at $2000 \times \mathrm{g}$ for 10 min at $4{ }^{\circ} \mathrm{C}$ to remove cells, lastly, at $10000 \times \mathrm{g}$ for $30 \mathrm{~min}$ at $4{ }^{\circ} \mathrm{C}$ to remove cell debris. Exosomes were pelleted by ultracentrifugation at $100,000 \times \mathrm{g}$ for $90 \mathrm{~min}$. They were 
resuspended in PBS and collected by ultracentrifugation again at $100,000 \times \mathrm{g}$ for $90 \mathrm{~min}$. The concentration of the exosomes were quantified by BCA (Beyotime, Shanghai, China) and exosomes were ready for cell treatment.

\section{Transmission electron microscopy}

Exosome pellets, dissolved in PBS buffer were dropped in a carbon-coated copper grid and then stained with $1 \%$ uranyl acetate. The samples were observed using a JEM1230 transmission electron microscope (JEOL, Japan).

\section{Measurement of particle size and concentration distribution}

Nanoparticles in exosome suspensions were analyzed using a Litesizer 500 (Anton Paar GmbH, Austria).

\section{Labeling and internalization of exosomes}

The purified exosomes were labeled with a PKH67 green fluorescent labeling kit (Sigma-Aldrich, St. Louis, USA), according to the manufacturer's instructions. Briefly, the washed exosome pellets were resuspended in $250 \mu \mathrm{l}$ of Dilution C, PKH67 (2 $\mu$ l) was diluted in $250 \mathrm{~mL}$ Dilution, then they were mixed gently for $3 \mathrm{~min}$, and an equivalent volume of $0.1 \%$ BSA was added to bind the excess PKH67. PKH67-labeled exosomes were extracted through ultracentrifugation and the pellets were suspend in PBS. Finally, the recipient cells were co-cultured with the PKH67-labeled exosomes for $4 \mathrm{~h}$ and $24 \mathrm{~h}$.Actin filaments were stained with Palloidin (red stain) (Beyotime, Shanghai, China). DNA were stained with DAPI (blue stain) (Abcam, Cambridge, MA, USA). Images were taken using a fluorescence microscope to confirm the presence of exosomes within the cells and analyzed by ImageJ software.

\section{LC-MS/MS analysis}

All peptide samples were dried by vacuum centrifugation and resuspended in $2 \% \mathrm{ACN}$ and $0.1 \% \mathrm{FA}$. Then, peptides weres separated by nanoLC-MS/MS using an UltiMate 3000 RSLCnano system (Thermo Fisher, Waltham, MA, USA) and analyzed by Q Exactive HF-X (Thermo Fisher, Waltham, MA, USA). Solvent A is $2 \%$ ACN, $0.1 \%$ FA and solvent B is $98 \%$ ACN, 0.1\% FA. Gradient elution was performed at $32{ }^{\circ} \mathrm{C}$ using linear gradients of $120 \mathrm{~min}$ at a flow rate of $400 \mathrm{nl} / \mathrm{min}: 1-4 \mathrm{~min}$ with $3 \%(\mathrm{v} / \mathrm{v})$ of s B, 4-6 min from 3 to $5 \%(\mathrm{v} / \mathrm{v}) \mathrm{B}, 6-$ $70 \mathrm{~min}$ from 5 to $15 \%(\mathrm{v} / \mathrm{v}) \mathrm{B}, 70-90 \mathrm{~min}$ from 15 to $30 \%(\mathrm{v} / \mathrm{v})$ B, $90-100 \mathrm{~min}$ from 30to $80 \%(\mathrm{v} / \mathrm{v})$ B, 100 110 min with $80 \%(\mathrm{v} / \mathrm{v})$ B, $110-120$ min with $3 \%(\mathrm{v} / \mathrm{v})$ A. MS spectra were acquired using 120,000 resolution with a mass range of $300-1500 \mathrm{~m} / \mathrm{z}$ and an AGC target of 3E6. MS2 spectra were acquired using 45,000 resolution and HCD fragmentation performed with collision energy approximately $32 \%$ NCE. In addition, we used a method of data-dependent top 20 on MS2 with an AGC target of $2 \mathrm{E} 5$. Isolation window was $1.0 \mathrm{~m} / \mathrm{z}$, charge exclusion was $\leq 2$ and $\geq 7$, and dynamic exclusion was set to $30 \mathrm{~s}$. The fixed first mass was $100 \mathrm{~m} / \mathrm{z}$, peptide match was preferred, and exclude isotopes was on.

\section{Peptide-protein identification and quantification}

MaxQuant (version 1.6.2.10) was used for protein identification and quantification (Cox and Mann, 2008; Cox et al.,2011). The human UniProtKB database (October 2018) and HBV-b/-c database (October 2018) were utilized as the search database, while the automatic reverse database and known contaminants were used for decoy search. Variable modifications included oxidation (M) $(+15.99491 \mathrm{Da})$, acetyl (protein $\mathrm{N}$-term) $(+42.01056 \mathrm{Da})$, and GlyGly(K)_10plex_TMT (+ 343.20586 Da). Carbamidomethyl $(\mathrm{C})(+57.02146 \mathrm{Da})$ was set as the fixed modification, and the max number of modifications per peptide was set to 5 . Trypsin was set as the specificity of digestion, and max missed cleavage sites was 2 . We used $20 \mathrm{ppm}$ in the first search ion tolerance and $4.5 \mathrm{ppm}$ in the main search ion tolerance. Both peptide and protein identification were performed at $\mathrm{FDR}<1 \%$. Except for the above-mentioned, the default parameters of MaxQuant were adopted.

\section{RNA extraction and qPCR}

RNA extraction kit (TaKaRa, Beijing, China) was used to extract RNA from cultured cells. The cDNA was generated using the PrimeScript RT reagent Kit (TaKaRa, Beijing, China). Evaluation of CD44 mRNA level was performed by using SYBR Premix Ex Taq Kits (TaKaRa, Beijing, China). The primer sequences of CD44 (forward:5' - AGTCACAGACCTGCCCAATGCCTTT-3' and reverse:5'-TTTGCTCCACCTTCTTGACTCCCA TG-3') and GAPDH (forward: 5'-GACAGTCAGC CGCATCTTCT-3' and reverse: 5'-TTAAAAGCAG CCCTGGTGAC-3') were used and then quantified using real-time PCR on $\mathrm{ViiA}^{\mathrm{Tw}} 7$ Real-Time PCR System (Life Technologies, CA, USA). For the $2-\Delta \Delta$ Ct method was used to evaluate the gene expression fold change among the groups. Three independent experiments were performed.

\section{Western blot analysis}

Cells or exosomes were lysed using a radioimmunoprecipitation assay (RIPA) lysis buffer (Beyotime, Shanghai, China) supplemented with PMSF inhibitor (Beyotime, Shanghai, China). Protein lysates were loaded and separated on a $10 \%$ sodium dodecyl sulfate polyacrylamide gel and transferred onto $0.22-\mu \mathrm{m}$ polyvinylidene fluoride (PVDF) membranes (Bio-Rad, Hercules, California, USA). The membranes were then blocked with Tris buffered saline Tween 20 (TBST) containing 5\% non-fat 
milk for $1 \mathrm{~h}$, and probed with primary antibodies overnight at $4{ }^{\circ} \mathrm{C}$. They were then washed three times with TBST for $10 \mathrm{~min}$ each and probed with secondary antibodies for $1 \mathrm{~h}$, followed by washing three times in TBST for $10 \mathrm{~min}$ per wash. The bands were visualized using an enhanced chemiluminescence (ECL) kit (Thermo Fisher, Waltham, MA, USA) in Image quant LAS400 mini (GE Healthcare, Munich, Germany). Primary antibodies against CD44 (Abclonal, Wuhan China), CD63, CD9, CD81, HSP70 (SBI, CA, USA) were used. Actin and GAPDH (Abcam, Cambridge, MA, USA) was the loading control.

\section{Statistical analysis}

All data were tested by $F$-test and expressed as mean \pm SEM. Differences were analyzed using two-tailed Student's t-tests to perform a statistical comparison between two groups or using one-way ANOVA among three groups. Statistical tests were performed using the SPSS software, version 20.0 (SPSS Inc.) or with GraphPad Prism 6.0 (GraphPad Software, Inc.). The level of statistical significance was set at ${ }^{*} p<0.05,{ }^{* * *} p<0.01$, **** $p<0.001$, ${ }^{* * * * * *} p<0.0001$.

\section{Results}

Identification of exosomes from human ovarian cancer cell lines HO8910 and HO8910PM

Human ovarian cancer cell line HO8910PM was regarded to have stronger invasive and metastatic potential than its parental cell line HO8910. We determined cellular migration and invasion ability of two cell lines using trans-well plate assays and verified that the numbers of migrated and invaded HO8910PM cells were significantly more than those of HO8910 cells (both $\mathrm{p}<$ 0.001), as shown in Fig. 1a and b. But CCK8 assay showed that cellular proliferation ability was similar between two cells within $96 \mathrm{~h}$ (Fig. 1c).

Next, we extracted and identified HO8910PM and HO8910 cell-derived exosomes (PMExos and HOExos). As shown in Fig. 1d, electron microscopy revealed that both PMExos and HOExos had a round or cup-shaped morphology, with the diameter ranging 50-250 nm (median $100 \mathrm{~nm}$ ) for PMExos and $50-200 \mathrm{~nm}$ (median100nm) for HOExos, respectively (Fig. 1e). Furthermore, both exosomes were enriched for exosome markers, including CD63, CD81, CD9 and HSP70 (Fig. 1f), suggesting that both cultured HO8910 and HO8910PM cells possess the ability to release exosomes.

\section{Exosomes derived from HO8910PM cells enhance aggressive phenotypes of $\mathrm{HO8910}$ cells}

To explore whether exosomes could be transferred between cells, $10 \mu \mathrm{g} / \mathrm{ml}$ of both PMExos and HOExos were labeled with PKH67 dye and then added into medium of cultured $5 \times 10^{4}$ of HO8910 cells. Confocal microscopy showed that green fluorescent signals appeared in HO8910 cells after $4 \mathrm{~h}$ of incubation, and obviously increased after overnight incubation at $37^{\circ} \mathrm{C}$, suggesting that HO8910 cells take in both PMExos and HOExos (Fig. 2a-b).

We next investigated the effect of ingested PMExos on the phenotypes of recipient HO8910 cells. HO8910 cells were treated with PBS, $10 \mu \mathrm{g} / \mathrm{ml}$ of HOExos and $10 \mu \mathrm{g} / \mathrm{ml}$ of PMExos, respectively. As shown in Fig. 2c-d, HO8910 cells treated with PMExos presented increased migration and invasion ability compared to negative controls $(p<$ 0.01 for migration, $p<0.05$ for invasion) and $\operatorname{PBS}(\mathrm{p}<0.01$ for migration, $\mathrm{p}<0.05$ for invasion), but HO8910 cells treated with HOExos did not change migration and invasion ability. Our results suggest that the stronger aggressive potential of HO8910PM cells can be transmitted to HO8910 cells via transferring exosomes, consequently enhancing metastatic potential of recipient cells.

\section{Screen and identification of molecules in donor exosomes affecting phenotypes of recipient cells}

To identify the molecules in exosomes from donor cells that play a role on the phenotypes of recipient cells, we performed mass spectrometry of HOExos and PMExos. Totally 23 proteins were present in all three biological replicate MS runs. Of those, 8 proteins were always expressed higher in PMExos than that in HOExos in three biological repeats. Reversely, 4 proteins were always expressed lower in PMExos. The function of these proteins was listed as Table 1. CD44 was selected for further study because it was reported to act as adhesive molecules in cell migration. As shown in Fig. 3a, CD44 showed higher expression level in PMExos than that in HOExos, when both CD63 and actin were used as internal controls. Consistently, CD44 was also higher in HO8910PM cells than that in HO8910 cells (Fig. 3b). Next, we found that CD44 protein level in HO8910 cells treated with PMExos was significantly increased compared to cells treated with HOExos and PBS, as shown in Fig. 3c. Contrarily, mRNA level of CD44 was not changed among cells treated with PMExos, HOExos and PBS (Fig. 3d), suggesting that elevated CD44 in HO8910 cells was derived from ingested PMExos, but not synthesized in recipient cells.

\section{Exosomal CD44 is a functional mediator in intercellular communication}

To further verify the role of CD44 in exosomes from donor cells in changing the phenotypes of recipient cells, we overexpressed CD44 in HO8910 cells through CD44 plasmid transfection (Fig. 4a), and found that HO8910 cells stably transfected with CD44 plasmids presented increased the ability of proliferation, migration $(\mathrm{p}<$ 

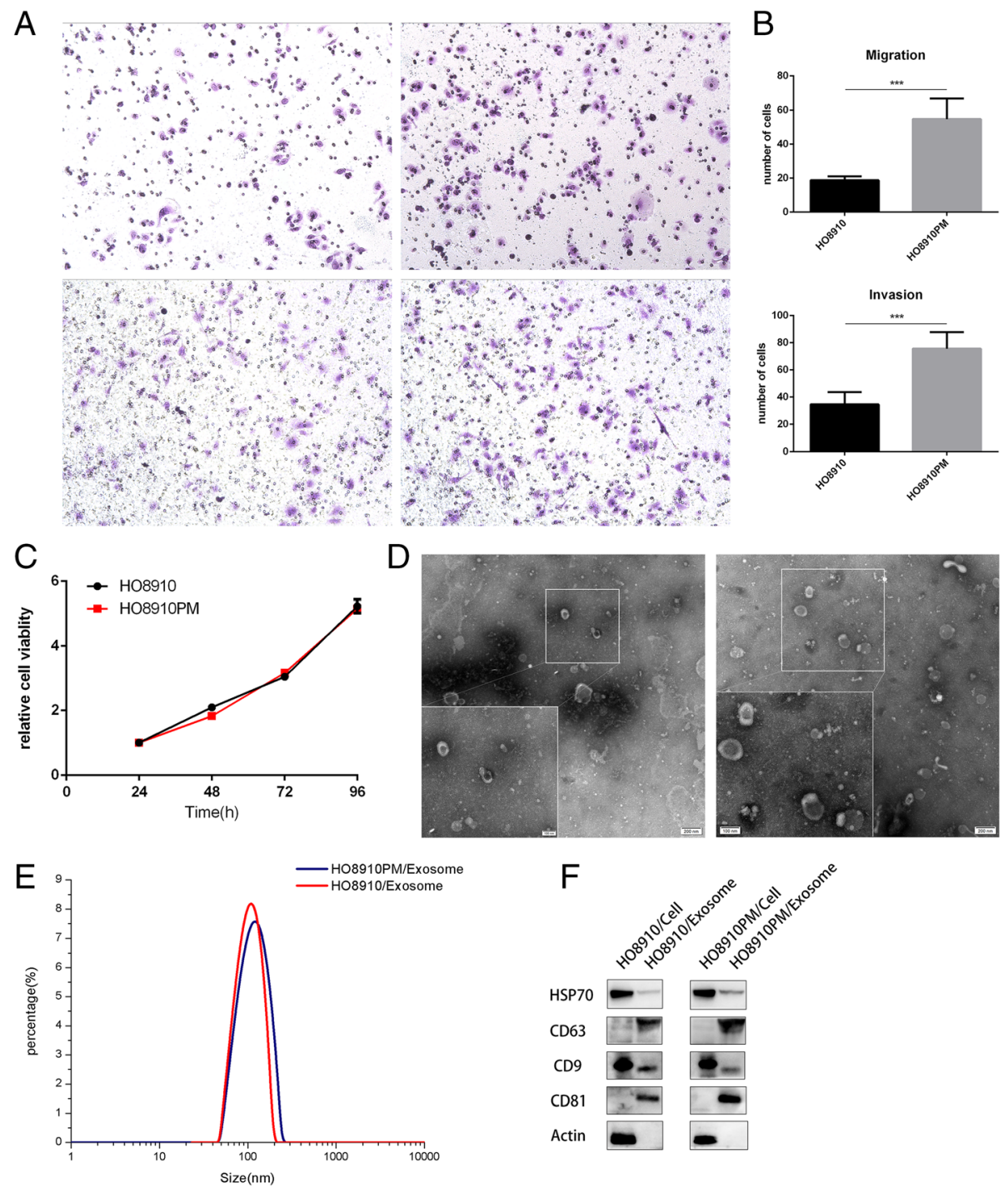

Fig. 1 Identification of exosomes from human ovarian cancer cell line HO8910 and HO8910PM. a and b migration and invasion assay. $2 \times 10^{5}$ and $3 \times 10^{5}$ of $\mathrm{HO} 8910$ and HO8910PM cells were respectively added to trans-well plates without or with Matrigel-coated, $24 \mathrm{~h}$ later, migration and invasion were assessed by trans-well assays. Results in A were representative of three experiments with similar results. Results in B were shown as means \pm SEM for three separate experiments. *** $p<0.001$. c Cell proliferation assay. $4 \times 10^{3}$ of HO8910 and HO8910PM cells were plated onto 96 -well plates. Cell proliferation in $24 \mathrm{~h}, 48 \mathrm{~h}, 72 \mathrm{~h}, 96 \mathrm{~h}$ was respectively assessed by CCK8 assays. Results were shown as means \pm SEM for three separate experiments. d Transmission electron microscopy. Transmission electron micrographs of purified exosomes secreted from HO8910 and HO8910PM cell lines. Scale bar, $200 \mathrm{~nm}$ and $100 \mathrm{~nm}$. e Nanoparticle analysis. Concentration and size distribution of nano-sized particles in exosome suspension were measured using Litesizer 500. f Western blot analysis. Exosomes, isolated from HO8910 and HO8910PM cell lines, and parental cellular lysates (10 $\mathrm{mg} / \mathrm{lane})$ were western blotted for HSP70, CD63, CD9 and CD81.Actin served as the control

$0.0001)$ and invasion $(p<0.001)$ compared to controls (Fig. 4b-e). We then extracted exosomes from HO8910 cells transfected with CD44 plasmids and empty vectors respectively, and incubated them with the HO8910 cells for $48 \mathrm{~h}$. The results revealed that exosomes from HO8910 cells transfected with CD44 plasmids promoted the ability of migration $(p<0.01)$ and invasion $(p<0.01)$, in HO8910 cells, compared to empty vectors (Fig. 4f), suggesting that exosomal CD44 is a functional mediator in intercellular communication, and CD44 in exosomes from donor cells changes the phenotypes of recipient cells.

\section{Discussion}

At present, a variety of methods for isolation and purification of exosomes have been developed [36], such as ultracentrifugation, gradient ultracentrifugation, coprecipitation, and others, in which ultracentrifugationbased exosome isolation is most commonly used. In our study, exosomes were successfully isolated from 
A
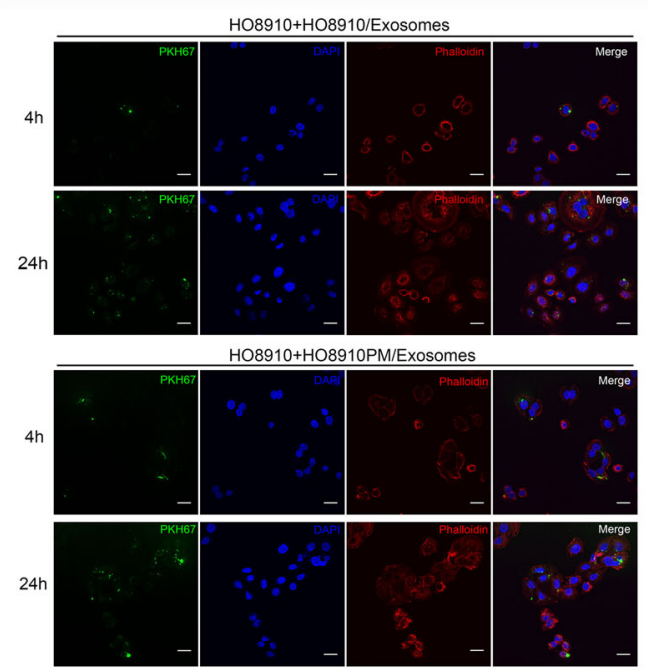

C

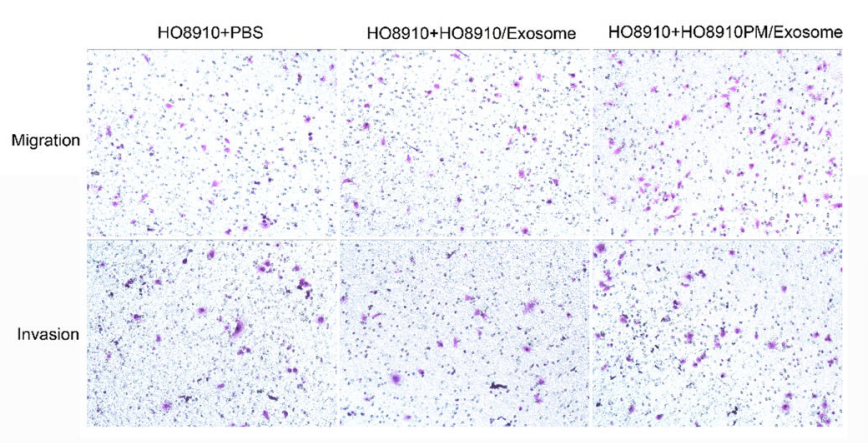

B
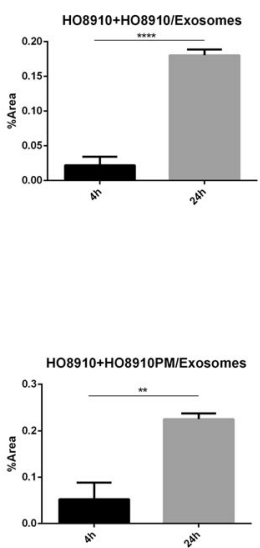

D
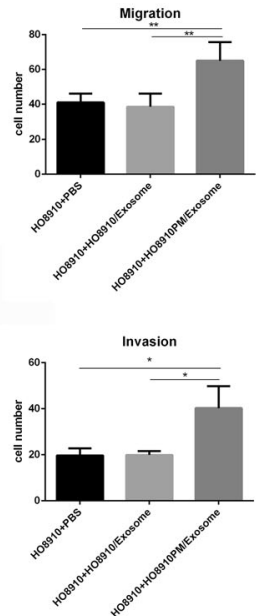

Fig. 2 Exosomes derived from HO8910PM cells enhance aggressive phenotypes of HO8910 cells. a-b Confocal microscopy. $5 \times 10^{4}$ HO8910 cells were cultured with exosomes labeled green fluorescent dye PKH67 for $4 \mathrm{~h}$ or $24 \mathrm{~h}$. HO8910 cells were observed under confocal microscopy at $600 \times$ magnification. DAPI was used to stain the nuclei and Palloidin was used to stain the cell cortex. Scale bar $20 \mu \mathrm{m}$. b Area fraction (\%Area) reflected the degree of PKH67 labeled exosomes uptaking by recipient cells. Data represented the means \pm SEM of three independent experiments. ${ }^{* * *} p<0.0001,{ }^{*} p<0.05$ compared to 0 h. $\mathbf{c}$-d Migration and invasion assays. $10 \mu \mathrm{g} / \mathrm{mL}$ of exosomes extracted from HO8910PM and HO8910 cells were incubated with HO8910 cells in 6-well plates for 48 h. PBS served as the control. $2 \times 10^{5}$ and $3 \times 10^{5}$ digested HO8910 cells were respectively added to trans-well plates without or with Matrigel-coated. Migration and invasion were assessed by trans-well assays after 24 h. Results in B were representative of three experiments. Results in D were shown as means \pm SEM for three separate experiments. One-way ANOVA was used to analyze the differences. ${ }^{* *} p<0.01$, ${ }^{*} p<0.05$

HO8910 and HO8910PM cells by the ultracentrifugation method. As it is hard to completely eliminate contamination pulled down from other sources in the culture medium, it is essential to identify exosomes using other approaches, including electron microscopy, particle tracking and western blotting [41]. Electron microscopy and particle tracking analysis revealed that both PMExos and HOExos had a round or cup-shaped morphology, with the diameter ranging $50-250 \mathrm{~nm}$ for PMExos and 50-200 nm for HOExos, respectively. Our results showed that the morphology and size were both fit to the characterization of exosomes, which were consistent with most of previous studies. As for protein markers, different cell types may have their own exosomal markers. According to the study from Théry et al., major histocompatibility complex (MHC), flotillin, and heat shock $70-\mathrm{kDa}$ proteins (HSP70) were found to similarly present in all EVs. Exosomes can be distinguished by immuno-isolation using either CD63, CD81, or CD9 [21]. Thus, we tried HSP70, CD9, CD63 and CD81 and found that CD81 and CD63 were only enriched in HOExos and PMExos whereas CD9 and HSP70 also 
Table 1 The function of proteins expressed differentially between PMExos and HOExos

\begin{tabular}{|c|c|c|c|}
\hline $\begin{array}{l}\text { Gene name of } \\
\text { proteins }\end{array}$ & $\begin{array}{l}\text { The expression level } \\
\text { in PMExos }\end{array}$ & $\begin{array}{l}\text { Fold } \\
\text { change }\end{array}$ & Function \\
\hline ATP1A1 & High & 2.394 & $\begin{array}{l}\text { This is the catalytic component of the active enzyme, which catalyzes the hydrolysis of ATP } \\
\text { coupled with the exchange of sodium and potassium ions across the plasma membrane. This } \\
\text { action creates the electrochemical gradient of sodium and potassium ions, providing the energy } \\
\text { for active transport of various nutrients }[25,49] \text {. }\end{array}$ \\
\hline TUBB & High & 3.368 & $\begin{array}{l}\text { Tubulin is the major constituent of microtubules. It binds two moles of GTP, one at an } \\
\text { exchangeable site on the beta chain and one at a non-exchangeable site on the alpha chain [15, } \\
35,43] \text {. }\end{array}$ \\
\hline EEF2 & High & 21.891 & Catalyzes the GTP-dependent ribosomal translocation step during translation elongation $[18,19]$. \\
\hline CD44 & High & 1.877 & $\begin{array}{l}\text { Cell-surface receptor that plays a role in cell-cell interactions, cell adhesion and migration, help- } \\
\text { ing them to sense and respond to changes in the tissue microenvironment }[29,31,38,45] \text {. }\end{array}$ \\
\hline RAB6B & High & 2.939 & $\begin{array}{l}\text { have a role in retrograde membrane traffic at the level of the Golgi complex and retrograde } \\
\text { transport in neuronal cells }[13,44] \text {. }\end{array}$ \\
\hline MSN & High & 1.506 & $\begin{array}{l}\text { Ezrin-radixin-moesin family protein that connects the actin cytoskeleton to the plasma } \\
\text { membrane and thereby regulates the structure and function of specific domains of the cell } \\
\text { cortex }[14,22] \text {. }\end{array}$ \\
\hline RAN & High & 2.893 & $\begin{array}{l}\text { GTPase involved in nucleocytoplasmic transport, participating both to the import and the export } \\
\text { from the nucleus of proteins and RNAs [34]. }\end{array}$ \\
\hline ACTG & High & 1.147 & $\begin{array}{l}\text { Actins are highly conserved proteins that are involved in various types of cell motility and in } \\
\text { maintenance of the cytoskeleton [8]. }\end{array}$ \\
\hline H2BFC & Low & 0.267 & Core component of nucleosome $[1,2]$. \\
\hline H2AFV & Low & 0.208 & Variant histone H2A which replaces conventional H2A in a subset of nucleosomes $[10,40]$. \\
\hline NID1 & Low & 0.615 & $\begin{array}{l}\text { Sulfated glycoprotein widely distributed in basement membranes and tightly associated with } \\
\text { laminin. Also binds to collagen IV and perlecan. It probably has a role in cell-extracellular matrix } \\
\text { interactions }[4,12,50] \text {. }\end{array}$ \\
\hline CLTC & Low & 0.879 & Clathrin is the major protein of the polyhedral coat of coated pits and vesicles [16]. \\
\hline
\end{tabular}

existed in cell lysates. Actin were served as internal control in this experiment. However, the expression level of actin was not detected in HO8910 and HO8910PM exosomes, which may be due to the huge expression difference of actin between cells and exosomes. In addition, we also noticed that the cell proliferation rate was similar between HO8910 and HO8910PM cells within $96 \mathrm{~h}$. It is likely that the difference of cell proliferation indexes between these two cell lines could be detected when culturing for an extended period of time.

It has been well-known that exosomes act as message passengers in tumor microenvironment, and exosome transport is believed to be an effective way to modulate cell signaling or biological behavior in recipient cells [48]. The nature of tumor heterogeneity has profound implications for tumor development and therapeutic outcomes. So, exosomes may take part in the progress of tumor heterogeneity and influence the metastasis and chemotherapy resistance of tumor. Previous studies on breast cancer, renal carcinoma and ovarian cancer have shown that exosomes secreted from resistant cancer cells can promote the chemoresistance of sensitive cancer cells [7, 27, 32, 37, 46, 51]. Besides the chemoresistance phenotype, exosomes can transfer the metastasis phenotype between distinct clones. For example, it has been reported that exosomes secreted by highly metastatic clonal variants of carcinomas induce metastatic behavior in poorly metastatic clones in several cancers, including colon cancer, osteosarcoma and pancreatic ductal adenocarcinoma [23, 26, 39]. However, it is little known in ovarian cancer. We used a pair of ovarian cancer cell lines with different ability of metastasis, HO8910 and HO8910PM, and found that exosomes from HO8910PM cells contributed to the increase in migration and invasion of HO8910 cells, indicating the fact that exosomes can transfer the metastasis phenotype between distinct clones, and the extensive metastatic ability of ovarian cancer are likely to be formed by the transfer of high metastatic capacity between tumor cells. Our findings may provide a new approach to block the metastasis of ovarian cancer. However, it was worth mentioning that the human ovarian cancer cell lines which were similar to characteristics of HO8910 and HO8910PMs are rare, so further experiments in vivo were needed to verify this idea.

The surface of exosomes was decorated by the parent cell-derived signaling molecules and their intravesicular contents, including DNA, mRNA, microRNA, as well as enzymes and soluble factors, all biologically active and capable of executing functional responses in target cells and reprogramming activities of these cells [33]. For example, previous research proved that TGF $\beta 1$ in 

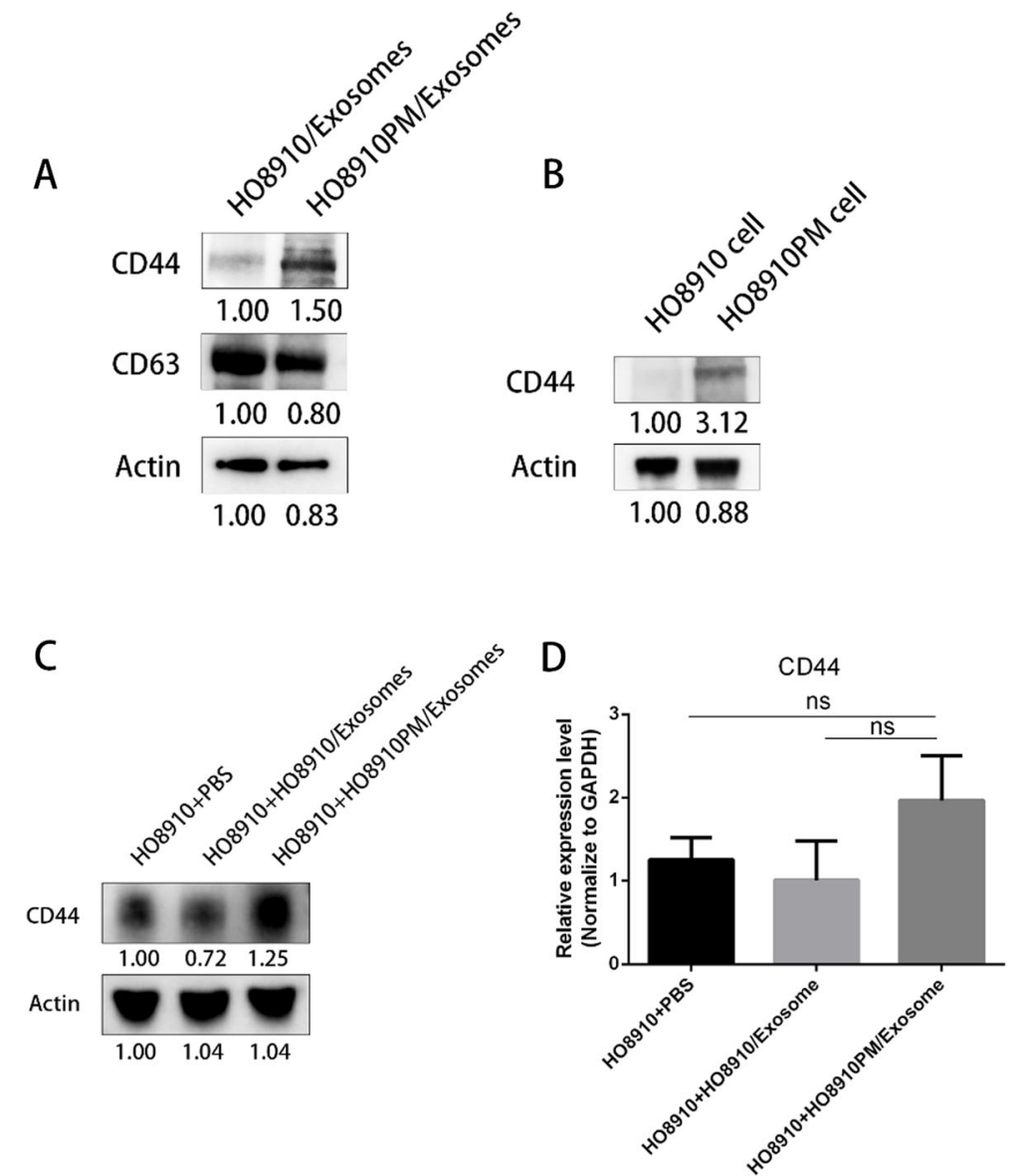

Fig. 3 Identification of molecules in donor exosomes affecting phenotypes of recipient cells. a Western blot analysis on expression levels of CD44

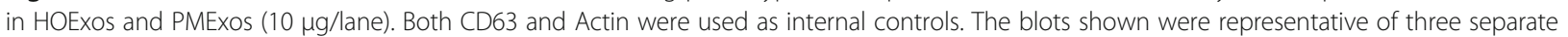
experiments. b Western blot analysis on expression levels of CD44 in HO8910 and HO8910PM cells (10 $\mu \mathrm{g} / \mathrm{lane}$ ). The blots shown were representative of three separate experiments. c $10 \mu \mathrm{g} / \mathrm{ml}$ of exosomes extracted from HO8910PM and HO8910 cells were incubated with HO8910 cells in 6-well plates for $48 \mathrm{~h}$. Adding PBS served as control. Thereafter, HO8910 cell lysates were collected, lysed and immunoblotting were performed $(10 \mu \mathrm{g} / \mathrm{lane})$. Actin was used as the internal control. The blots shown were representative of three separate experiments. $\mathbf{d}$ Real-time qRT-PCR. $10 \mu \mathrm{g} / \mathrm{ml}$ of exosomes extracted from HO8910PM and HO8910 cells were incubated with HO8910 cells in 6-well plates for $48 \mathrm{~h}$. PBS served as the control. Extracted RNA of HO8910 cells was used for qRT-PCR analysis. CD44 mRNA was detected by RT-PCR. GAPDH was used as the internal control. Results were shown as means \pm SEM for three separate experiments. NS meant no significant difference

fibroblasts-derived exosomes promoted epithelial mesenchymal transition of ovarian cancer cells [24]. Besides proteins, many non-coding RNAs have been reported to be transferred through exosomes. Au yeung found that exosomal transfer of stroma-derived miR21 conferred paclitaxel resistance in ovarian cancer cells through targeting APAF 1[3]. Qu showed that exosome-transmitted lncARSR promoted sunitinib resistance in renal cancer [32]. In order to explore the factors inside exosomes that play a role in this process, we using MS analysis and Western blot confirmed that CD44 showed a higher expression in HO8910PM cells and their secreted exosomes. Because there are no consensus of internal control in exosomes, CD63, actin and GAPDH all are reported to be used as internal control [29], so in our study, we used both CD63 and Actin as internal controls to compare the expression level of CD44 between PMExos and HOExos. It has been reported that CD44 plays a role in cell-cell interactions, cell adhesion, migration and acts as a metastasis-promoting molecule in many types of cancer [29, 31, 38, 45]. As we expected, overexpression of $\mathrm{CD} 44$ promoted the migration, invasion and proliferation of HO8910 cells. Interestingly, CD44 protein levels were increased in HO8910 cells upon the uptake of HO8910PM-derived exosomes. Exosomes derived from HO8910 cells transfected with CD44 plasmids promoted cell migration and invasion of HO8910 cells. Our findings suggest that exosome-mediated transfer of CD44 acts as a promoter of metastatic behavior in the recipient cells. 
A

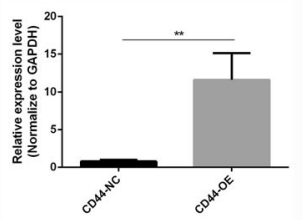

B

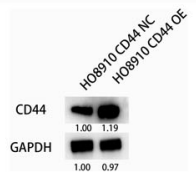

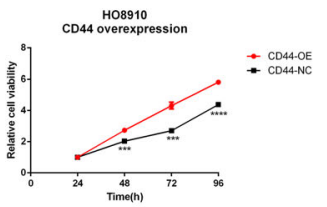

C

CD44-NC

CD44-OverExpression

D

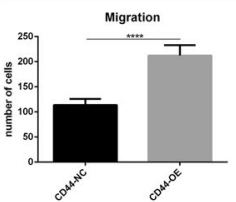

Migration

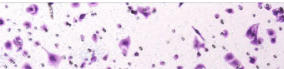

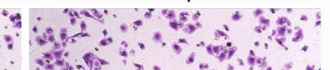<smiles>[C]1CC1</smiles>
a

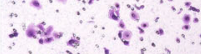
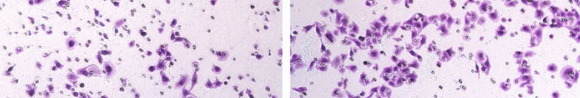

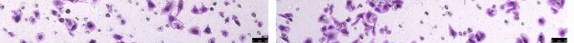

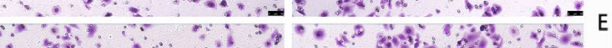

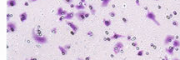

Invasion
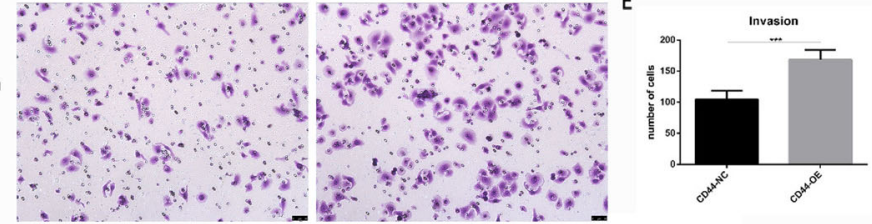

$\mathrm{F}$

HO8910+NC/Exosomes

HO8910+CD440E/Exosomes

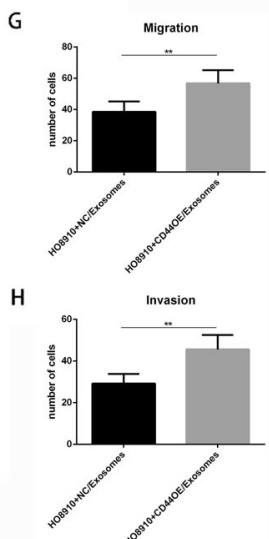

Fig. 4 Exosomal CD44 is a functional mediator in intercellular communication. a Real-time qRT-PCR and Western blotting. qRT-PCR of CD44 mRNA expression after transfecting with CD44 overexpression plasmid for $24 \mathrm{~h}$ and treating with $500 \mu \mathrm{g} / \mathrm{ml}$ of G418 for 2 weeks. Cell transfected with the empty vectors acted as controls. Results were shown as means \pm SEM for three separate experiments, ${ }^{* *} p<0.01$. Western blot analysis on cells mentioned above to validate the protein level of CD44 (10 $\mu \mathrm{g} / \mathrm{lane}$ ). The blots shown were representative of three separate experiments. b Cell proliferation assay. $4 \times 10^{3}$ H08910 cells transfected with CD44 overexpression plasmids and with empty vectors were added to 96 -well plates. $24 \mathrm{~h}, 48 \mathrm{~h}, 72 \mathrm{~h}, 96 \mathrm{~h}$ of cell viability were respectively assessed by CCK8 assays. Results in B were shown as means \pm SEM for three separate experiments, ${ }^{* * *} p<0.001,{ }^{* * * *} p<0.0001$. c-h migration and invasion assay. $2 \times 10^{5}$ HO8910 cells transfected with CD44 overexpression plasmids and with empty vectors were respectively added to trans-well plates, and $3 \times 10^{5}$ cells mentioned above were added to with trans-well plates with matrigel-coated.24 $\mathrm{h}$ later, migration and invasion were assessed by trans-well assays. Results in $\mathrm{C}$ and $\mathrm{F}$ were representative of three experiments. Results in D, E, G, H were shown as means \pm SEM for three separate experiments, ${ }^{* *} p<0.01,{ }^{* * *} p<0.001,{ }^{* * *} p<0.0001$

\section{Conclusion}

In summary, we demonstrate that exosomes secreted from highly metastatic HO8910PM cells can promote migration and invasion of lower metastatic HO8910 cells through the transfer of CD44, which suggest that the more aggressive subpopulation can transfer a metastatic phenotype to the less one via secreting exosomes within a heterogeneous tumor. Our findings may provide a potential therapeutic approach for ovarian cancer.

\section{Acknowledgements}

Not applicable.

\section{Authors' contributions}

Xiameng Shen, Conghui Wang and Weiguo Lu conceived and designed the experiments both as first author. Xiameng Shen, Huihui Zhu and Yaping Wang performed the experiments. Xiameng Shen analyzed the data. Xinyu Wang, Xiaodong Chen and Weiguo Lu funded the projects. Xiameng Shen wrote the original draft. Wanzhong Ge and Weiguo Lu revised the manuscript. All authors read and approved the final manuscript. 


\section{Funding}

This work was supported by National Natural Science Foundation of China [grant number 82072856 and 81974402]; Medical and health research project of Zhejiang Province [grant number 2017211914] and key research and development project of Zhejiang Province [grant number 2019C03010].

\section{Availability of data and materials}

Not applicable.

\section{Ethics approval and consent to participate}

Not applicable.

\section{Consent for publication}

Not applicable.

\section{Competing interests}

The authors declare that they have no competing interests.

\section{Author details}

'Department of Gynecologic Oncology, Women's Hospital School of Medicine Zhejiang University, No. 1 Xueshi Road, Hangzhou 310006, China. 'Women's Reproductive Health Research Laboratory of Zhejiang Province, Women's Hospital School of Medicine Zhejiang University, Hangzhou, China. ${ }^{3}$ Zhejiang University Cancer Center, Hangzhou, China.

\section{Received: 19 October 2020 Accepted: 25 January 2021}

\section{Published online: 24 February 2021}

\section{References}

1. Albig W, Trappe R, Kardalinou E, Eick S, Doenecke D. The human H2A and H2B histone gene complement. Biol Chem. 1999;380:7-18.

2. Andersen JS, Lam YW, Leung AK, Ong SE, Lyon CE, Lamond Al, Mann M Nucleolar proteome dynamics. Nature. 2005;433:77-83.

3. Au Yeung $\mathrm{CL}, \mathrm{Co} \mathrm{N}$, Tsuruga $\mathrm{T}$, Yeung $\mathrm{T}$, Kwan $\mathrm{S}$, Leung CS, et al. Exosoma transfer of stroma-derived miR21 confers paclitaxel resistance in ovarian cancer cells through targeting APAF1. Nat Commun. 2016;7:11150.

4. Aumailley M, Wiedemann H, Mann K, Timpl R. Binding of nidogen and the laminin-nidogen complex to basement membrane collagen type IV. Eur J Biochem. 1989;184:241-8.

5. Boyiadzis M, Whiteside TL. Information transfer by exosomes: A new frontier in hematologic malignancies. Blood Rev. 2015;29(5):281-90.

6. Brinton LT, Sloane HS, Kester M, Kelly KA. Formation and role of exosomes in cancer. Cell Mol Life Sci. 2015:72:659-71.

7. Chen WC, Liu XM, Lu MM, Chen L, Zhao JH, Zhang SL, et al. Exosomes from Drug-Resistant Breast Cancer Cells Transmit Chemoresistance by a Horizontal Transfer of MicroRNAs. PLoS One. 2014;9(4):e95240.

8. Chou CC, Davis RC, Fuller ML, Slovin JP, Wong A, Wright J, et al. Gammaactin: unusual mRNA 3'-untranslated sequence conservation and amino acid substitutions that may be cancer related. Proc Natl Acad Sci U S A. 1987;84: 2575-9.

9. Dick JE. Stem cell concepts renew cancer research. Blood. 2008;112:4793807.

10. Draker $R$, Cheung P. Transcriptional and epigenetic functions of histone variant H2A.Z. Biochem Cell Biol. 2009;87:19-25.

11. Fidler IJ, Hart IR. Biological diversity in metastatic neoplasms: origins and implications. Science. 1982;217:998-1003.

12. Fazio MJ, O'Leary J, Kahari VM, Chen YQ, Saitta B, Uitto J. Human nidogen gene: structural and functional characterization of the $5^{\prime}$-flanking region. J Invest Dematol. 1991;97:281-5.

13. Garcia-Saez I, Tcherniuk S, Kozielski F. The structure of human neuronal Rab6B in the active and inactive form. Acta Crystallogr D Biol Crystallogr. 2006;62:725-33.

14. Gary R, Bretscher A. Heterotypic and homotypic associations between ezrin and moesin, two putative membrane-cytoskeletal linking proteins. Proc Natl Acad Sci U S A. 1993:90:10846-50.

15. Hall JL, Dudley L, Dobner PR, Lewis SA, Cowan NJ. Identification of two human beta-tubulin isotypes. Mol Cell Biol. 1983:3:854-62

16. Hanspal M, Luna E, Branton D. The association of clathrin fragments with coated vesicle membranes. J Biol Chem. 1984:259:11075-82.

17. Heppner GH. Tumor heterogeneity. Cancer Res I. 1984;44:2259-65.
18. Kaneda Y, Yoshida MC, Kohno K, Uchida T, Okada Y. Chromosomal assignment of the gene for human elongation factor 2. Proc Natl Acad Sci U S A. 1984;81:3158-62.

19. Kapp LD, Lorsch JR. The molecular mechanics of eukaryotic translation. Annu Rev Biochem. 2004;73:657-704.

20. Keller S, Ridinger J, Rupp AK, Janssen JW, Altevogt P. Body fluid derived exosomes as a novel template for clinical diagnostics. J Transl Med. 2011;9:86.

21. Kowal J, Arras G, Colombo M, Jouve M, Morath JP, Primdal-Bengtson B, Dingli F, Loew D, Tkach M, Thery C. Proteomic comparison defines novel markers to characterize heterogeneous populations of extracellular vesicle subtypes. Proceed Nat Acad Sci. 2016;113:E968-77.

22. Lankes WT, Furthmayr H. Moesin: A member of the protein 4.1-Talin-ezrin family of proteins. Proc Natl Acad Sci U S A. 1991;88:8297-301.

23. Li Z, Jiang $P$, Li J, Peng M, Zhao X, Zhang $X$, et al. Tumor-derived exosomal Inc-Sox2ot promotes EMT and stemness by acting as a ceRNA in pancreatic ductal adenocarcinoma. Oncogene. 2018;37:3822-38.

24. Li WQ, Zhang XX, Wang J, Li MC, Cao CH, Tan JH, et al. TGFß-1 in fibroblasts-derived exosomes promotes epithelial- mesenchymal transition of ovarian cancer cells. Oncotaget. 2017;56:96035-47.

25. Lingrel JB, Orlowski J, Shull MM, Price EM. Molecular genetics of $\mathrm{Na}, \mathrm{K}$ ATPase. Prog Nucleic Acid Res Mol Biol. 1990;38:37-89.

26. Macklin R, Wang H, Loo D, Martin S, Cumming A, Cai N, et al. Extracellular vesicles secreted by highly metastatic clonal variants of osteosarcoma preferentially localize to the lungs and induce metastatic behaviour in poorly metastatic clones. Oncotarget. 2016;7:43570-87.

27. Mao L, Li J, Chen W, Cai Y, Yu D, Zhong S, et al. Exosomes decrease sensitivity of breast cancer cells to adriamycin by delivering microRNAs. Tumor Biol. 2016:37:5247-56.

28. Nicolson GL. Generation of phenotypic diversity and progression in metastatic tumor cells. Cancer Metastasis Rev. 1984:3:25-42.

29. Nakamura K, Sawada K, Kinose Y, Yoshimura A, Toda A, Nakatsuka E, et al. Exosomes promote ovarian Cancer cell invasion through transfer of CD44 to peritoneal Mesothelial cells. Mol Cancer Res. 2017;15(1):78-92.

30. Pan BT, Johnstone RM. Fate of the transferrin receptor during maturation of sheep reticulocytes in vitro: selective externalization of the receptor. Cell. 1983:33(3):967-78.

31. Ponta H, Sherman L, Herrlich PA. CD44: From adhesion molecules to signalling regulators. Nat Rev Mol Cell Biol. 2003;1(4):33-45.

32. Qu L, Ding J, Chen C, Wu Z, Liu B, Gao Y, et al. Exosome-transmitted IncARSR promotes Sunitinib resistance in renal Cancer by acting as a competing endogenous RNA. Cancer Cell. 2016;29:653-68.

33. Record M, Subra C, Silvente-Poirot S, Poirot M. Exosomes as intercellular signalosomes and pharmacological effectors. Biochem Pharmacol. 2011;81: 1171-82.

34. Ren M, Villamarin A, Shih A, Coutavas E, Moore MS, LoCurcio M, et al. Separate domains of the ran GTPase interact with different factors to regulate nuclear protein import and RNA processing. Mol Cell Biol. 1995;15: 2117-24.

35. Romaniello R, Arrigoni F, Bassi MT, Borgatti R. Mutations in alpha- and betatubulin encoding genes: implications in brain malformations. Brain and Development. 2015;37:273-80.

36. Shao H, Im H, Castro CM, Breakefield X, Weissleder R, Lee H. New Technologies for Analysis of Extracellular Vesicles. Chemical Rev. 2018;118: 1917-50.

37. Samuel P, Mulcahy LA, Furlong F, McCarthy HO, Brooks SA, Fabbri M, et al. Cisplatin induces the release of extracellular vesicles from ovarian cancer cells that can induce invasiveness and drug resistance in bystander cells. Philos Trans R Soc Lond B Biol Sci. 2018;373(1737): 20170065

38. Sawada K, Ohyagi-Hara C, Kimura T, Morishige K. Integrin inhibitors as a therapeutic agent for ovarian cancer. J Oncol. 2012;2012:915140.

39. Schillaci O, Fontana S, Monteleone F, Taverna S, Di Bella MA, Di Vizio D, et al. Exosomes from metastatic cancer cells transfer amoeboid phenotype to non-metastatic cells and increase endothelial permeability: their emerging role in tumor heterogeneity. Sci Rep. 2017;7:1-15.

40. Thambirajah AA, Li A, Ishibashi T, Ausio J. New developments in posttranslational modifications and functions of histone $\mathrm{H} 2 \mathrm{~A}$ variants. Biochem Cell Biol. 2009:87:7-17.

41. Thery C, Amigorena S, Raposo GA, Clayton A. Isolation and characterization of exosomes from cell culture supernatants and biological fluids. Curr Protocols Cell Biol. 2006;30:3.22.1-3.22.29. 
42. Torre LA, Trabert B, DeSantis CE, Miller KD, Samimi G, Runowicz CD, et al. Ovarian cancer statistics. CA Cancer J Clin. 2018;68(4):284-96.

43. Volz A, Weiss E, Trowsdale J, Ziegler A. Presence of an expressed beta-tubulin gene (TUBB) in the HLA class I region may provide the genetic basis for HLA-linked microtubule dysfunction. Hum Genet. 1994;93:42-6.

44. Wanschers BF, van de Vorstenbosch R, Schlager MA, Splinter D, Akhmanova A, Hoogenraad CC, et al. A role for the Rab6B Bicaudal-D1 interaction in retrograde transport in neuronal cells. Exp Cell Res. 2007; 313:3408-20,

45. Ween MP, Oehler MK, Ricciardelli C. Role of versican, hyaluronan and CD44 in ovarian cancer metastasis. Int J Mol Sci. 2011;12:1009-29.

46. Wei Y, Lai X, Yu S, Chen S, Ma Y, Zhang Y, et al. Exosomal miR-221/222 enhances tamoxifen resistance in recipient ER-positive breast cancer cells. Breast Cancer Res Treat. 2014:147:423-31.

47. Whiteside TL. Tumor-derived Exosomes and their role in Cancer progression. Adv Clin Chem. 2016;74:103-41.

48. Whiteside TL. Immune modulation of T-cell and NK (natural killer) cell activities by TEXs (tumourderived exosomes). Biochem Soc Trans. 2013;41: 245-51.

49. Xie Z, Cai T. Na+-K+ATPase-mediated signal transduction: from protein interaction to cellular function. Mol Interv. 2003:3:157-68.

50. Yurchenco PD, Schittny JC. Molecular architecture of basement membranes. FASEB J. 1990:4:1577-90

51. Zhang F, Zhu Y, Zhao Q, Yang D, Dong Y, Jiang L, et al. Microvesicles mediate transfer of P-glycoprotein to paclitaxel-sensitive A2780 human ovarian cancer cells, conferring paclitaxel-resistance. Eur J Pharmacol. 2014; 738:83-90

\section{Publisher's Note}

Springer Nature remains neutral with regard to jurisdictional claims in published maps and institutional affiliations.

Ready to submit your research? Choose BMC and benefit from:

- fast, convenient online submission

- thorough peer review by experienced researchers in your field

- rapid publication on acceptance

- support for research data, including large and complex data types

- gold Open Access which fosters wider collaboration and increased citations

- maximum visibility for your research: over $100 \mathrm{M}$ website views per year

At $\mathrm{BMC}$, research is always in progress.

Learn more biomedcentral.com/submissions 